\section{Nizozemska bolest u Bolivarijanskoj Republici Venezueli}

\section{Dutch disease in the Bolivarian Republic of Venezuela}

\section{Sažetak}

Venezuela je od svog osamostaljenja gospodarstvo temeljila na proizvodnji i izvozu jednog proizvoda. U 19. stoljeću to su bili kava i kakaovac koje je u 20. stoljeću zamijenila nafta. Navedeno je dovelo do nizozemske bolesti koja je gušila ostale gospodarske grane, pa su često korumpirane vlasti kupovale socijalni mir socijalističkim politikama i državnom potrošnjom. 1980-ih došlo je do prvog značajnijeg pada cijene nafte u 20. stoljeću te je Venezuela morala provesti liberalne reforme kako bi dobila pomoć Međunarodnog monetarnog fonda. Uslijedio je veliki pad standarda i BDP-a te masovni prosvjedi. Na valu tog nezadovoljstva na izborima 1998. godine pobjeđuje bivši vojni časnik i neuspjeli pučist Hugo Chavez kojemu oporavak cijene nafte omogućuje pokretanje socijalističkih reformi i gospodarski oporavak zemlje. Eksproprijacije vlasništva privatnih poduzeća i uvođenje cjenovnih ograničenja oslabili su domaće gospodarstvo i uzrokovali inflaciju, dok je rast državne potrošnje opteretio javne financije. Veliki pad cijene nafte 2014. uzrokovao je kolaps venezuelanskog gospodarstva kao i socijalnu i političku krizu. Prilikom izrade rada korišteni su službeni podatci venezuelanske vlade, ministarstava i instituta, te podaci Ujedinjenih Naroda, Svjetske Banke i ostalih organizacija kao i informacije iz venezuelanskih i inozemnih tiskovina i novinskih portala.

Ključne riječi: Hugo Chavez, Venezuela, naftna ekonomija, nizozemska bolest

\section{JEL klasifikacija: 054, 03}

\section{Abstract}

Ever since its independence, Venezuela has based its economy on the manufacturing and export of a single product. In the 19th century, those products were cocoa and coffee beans, which were replaced by oil in the 20th century. This led to the Dutch disease which harmed other sectors of the economy, so the often corrupt governments bought social peace with socialist policies and government spending. During the 1980 s, the first significant plunge in oil prices in the 20th century forced the Venezuelan government to conduct liberal reforms in order to receive assistance from the International Monetary Fund. These led to a significant decline in the standard of living and GDP, as well as, mass protests. Due to the popular discontent, the 1998 presidential elections were won by Hugo Chavez, a former military officer and the leader of the failed coup, who used the rebound in oil prices to start socialist reforms and economic recovery. Expropriations of privately owned assets and price controls weakened the domestic economy and led to inflation, while the rise in government spending strained the public finances. The big drop in oil price in 2014 caused the collapse of Venezuelan economy as well as social and political crisis. The data used in making this paper is from the Venezuelan government and its departments and institutes, as well as from the United Nations, the World Bank, other organisations and Venezuelan and foreign newspapers and web portals.

Keywords: Hugo Chavez, Venezuela, oil economy, Dutch disease

JEL classification: 054,03
Doc. dr.sc. Hrvoje Jošić

Ekonomski fakultet Sveučilišta u Zagrebu E-mail:hjosic@efzg.hr

Fran Maček Pandak, univ. bacc. oec. E-mail:fran.macek94@gmail.com

Asst. prof. Hrvoje Jošić, PhD

Faculty of Economics and Business, University of Zagreb E-mail:hjosic@efzg.hr

Fran Maček Pandak, univ. bacc. oec. E-mail:fran.macek94@gmail.com 
Jošić, H., Maček Pandak, F.

Nizozemska bolest $u$

Bolivarijanskoj Republici Venezueli

\section{Uvod}

Otkriće nafte 1910-ih godina uzrokovalo je gospodarski zamah koji je tada siromašnu poljoprivrednu zemlju do 1970-ih pretvorio u državu s najvišim standardom na kontinentu (Haggerty, 1990.). Izvoz nafte također je doveo do takozvane nizozemske bolesti, stanja u kojem izvozna oslonjenost na samo jedan proizvod dovodi do povećanja potražnje za domaćom valutom kojom se taj proizvod plaća te posljedično, do njene aprecijacije, što dovodi do poskupljenja svih domaćih proizvoda na međunarodnom tržištu te u konačnici, do pada konkurentnosti i stagnacije ostalih gospodarskih sektora. Učinke zaostajanja ostalih sektora venezuelanske su vlade ublažavale transfernim plaćanjima i otvaranjem radnih mjesta u javnom sektoru, što je financirano izdašnim naftnim prihodima, no zbog stabilnih cijena nafte kroz proteklih 100 godina, naftna ovisnost gospodarstva nije brinula venezuelanske vlade.

Naftni šok uzrokovan arapskim embargom 1973. doveo je do prvog velikog skoka cijena nafte, no do 1982. cijena se vratila gotovo na staru razinu te je Venezuela bila prisiljena smanjiti državnu potrošnju. Uslijedila je recesija te se prvi put u Venezueli javila značajnija inflacija. Godine 1989. predsjednikom postaje Carlos Perez, koji, suprotno obećanjima, liberalizira tržište te omogućuje rast bruto domaćeg proizvoda (BDP-a), ali njegove politike istodobno uzrokuju socijalno raslojavanje, rast nezaposlenosti i skok cijena goriva, a deregulacija 1994. godine dovodi do bankarske krize (Rosen, 2010.). Stanje se promijenilo izbornom pobjedom Huga Chaveza koji donosi novi ustav, mijenja ime zemlje u Bolivarijanska Republika Venezuela te uspostavlja državnu kontrolu nad naftnom industrijom i ponovno pokreće naftno gospodarstvo po uzoru na svoje prethodnike iz 60-ih i 70-ih godina prošlog stoljeća. Chavez svoje politike kolektivno naziva bolivarijanskom revolucijom, $u$ čast Simona Bolivara, revolucionarnog vođe iz vremena ratova za neovisnost. Proklamirani cilj bolivarijanske revolucije je uvođenje „socijalizma za 21. stoljeće“"koji se bazira na radničkoj kooperaciji te ostvarivanje regionalne suradnje na južnoameričkom kontinentu, no ona će u konačnici dovesti do politički kontrolirane ekonomije, korupcije i sve goreg međunarodnog položaja Venezuele.

Cilj ovog rada je prikazati efekte ekspanzivnih gos- podarskih politika vlada Huga Chaveza i njegovog nasljednika Nicolasa Madura na temeljne makroekonomske pokazatelje venezuelanskog gospodarstva, s obzirom na njihovu oslonjenost na naftu. Kako bi se to učinilo, uspostaviti će se uzročno posljedične veze između kretanja BDP-a, obujma vanjske trgovine te stanja javnih financija s prihodima od nafte na koje utječe egzogeni faktor (cijena nafte) i državna politika prema naftnoj industriji. Također će se prikazati utjecaj interveniranja u gospodarstvo i monetarni sustav na proizvodnju, tečaj, inflaciju te investicije. Kako bi se to učinilo, korišteni su podaci venezuelanskih i međunarodnih institucija, kao i izvještaji stranih i venezuelanskih novinskih listova, budući da venezuelanska vlada više ne prati ili ne objavljuje određene gospodarske podatke.

\section{Značaj nafte za venezuelansko gospodarstvo}

Kratkotrajni rast cijena nafte omogućio je Chavezovoj vladi gospodarski rast ubrzo po dolasku na vlast, no sumnjičavost investitora prema novom ljevičarskom predsjedniku te protivnici u državnim poduzećima doveli su do gospodarskog pada 2001.

Krajem 2002. godine, Chavezova opozicija je preko sindikata i gospodarske komore pokrenula štrajk u Petróleos de Venezuela, S.A. (PDVSA), nacionalnoj naftnoj kompaniji i najvećem proizvođaču nafte u zemlji. Dvomjesečni štrajk imao je za cilj natjerati Chaveza na ostavku, ili barem na raspisivanje prijevremenih izbora, a u njemu su uglavnom sudjelovali menadžeri, inženjeri i stručni kadar, dok su obični radnici većinom stali uz vlast i nastavili s radom. Čitav sustav, od naftnih crpilišta preko rafinerija i tankera pa do benzinskih postaja je prestao funkcionirati. Uskoro je došlo do nestašice benzina i do uličnih nereda, a Venezuela se našla u situaciji da mora uvoziti gorivo iz inozemstva. Štrajk je na prijedlog tadašnjeg generalnog direktora i Chavezovog bliskog suradnika, Alía Rodrígueza riješen 2003. otpuštanjem 18.000 štrajkaša (Wilpert, 2004.), što je dovelo do stabilizacije poduzeća, ali je imalo i negativan utjecaj na nastavak proizvodnje jer su otišli uglavnom iskusni i obrazovani kadrovi. Period od 2003., kada vlada stavlja pod kontrolu naftnu industriju, pa do svjetske recesije 2008. godine bilo je razdoblje najvećeg gospodarskog rasta 


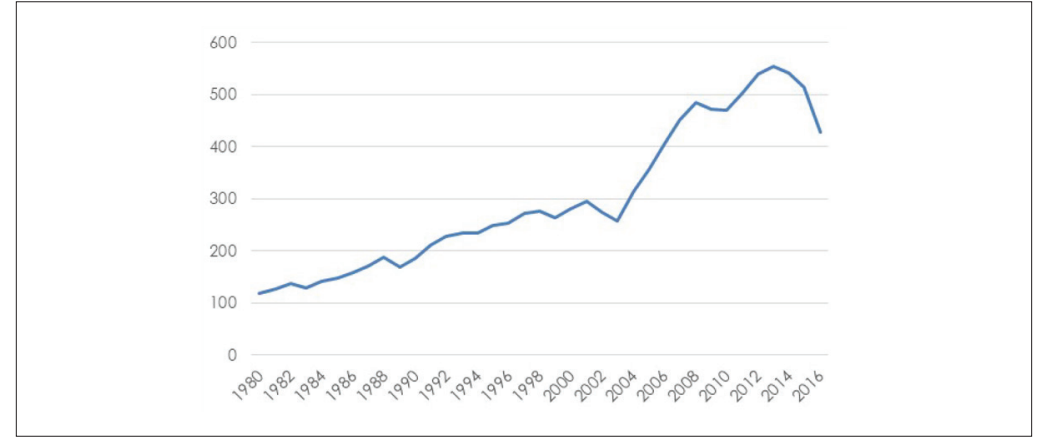

Izvor: MMF.

u Venezueli još od naftnog šoka 1973. Naftnim prihodima financirane su „Bolivarijanske misije“, socijalno-ekonomski programi kojima je prepolovljeno siromaštvo te proširen obuhvat zdravstvene, komunalne i energetske mreže. Realni BDP je u idućih 5 godina porastao za $94,7 \%$, odnosno u prosjeku 13,5\% godišnje (Weisbrot i Sandoval, 2009.), no treba uzeti u obzir da se najveći rast dogodio 2003., u vrijeme oporavka od štrajka. Promjene u BDP-u prikazane su na Slici 1.

Gospodarska ekspanzija bila je praćena i monetarnom ekspanzijom što je dovelo do inflacije po prosječnoj stopi od $20 \%$ godišnje. U tom razdoblju naftni sektor ostvaruje sporiji, povremeno i negativni rast od ne-naftnoga (Weisbrot i Sandoval, 2009.) zbog odlaska najstručnijih kadrova iz PDVSA, koja postaje politički kadrovirana nakon štrajka. Unatoč fiskalnoj ekspanziji i otvaranju poslova u javnim poduzećima i administraciji, privatni sektor je u tom periodu ostvarivao veće stope rasta od javnog, sve do 2008. kada se počeo osjećati utjecaj globalne recesije. Venezuela se od te recesije nikad nije u potpunosti oporavila jer su javna poduzeća, koja su često držala monopol u strateškim sektorima, zbog lošeg rukovodstva sve lošije poslovala, a krah naftnih cijena 2014. godine uzrokovao je krah gospodarstva. Venezuela je većinu 20. stoljeća svoje gospodarstvo temeljila na izvozu energenata čije su fluktuacije u cijeni uzrokovale fluktuacije u gospodarstvu zemlje. Do početka 21. stoljeća, naftna industrija činila je oko $80 \%$ izvoznih prihoda i oko $50 \%$ prihoda javnog sektora, a njena važnost se

Slika 2.Utjecaj promjene cijene nafte na stopu promjene BDP-a Venezuele (1987. - 2016.)

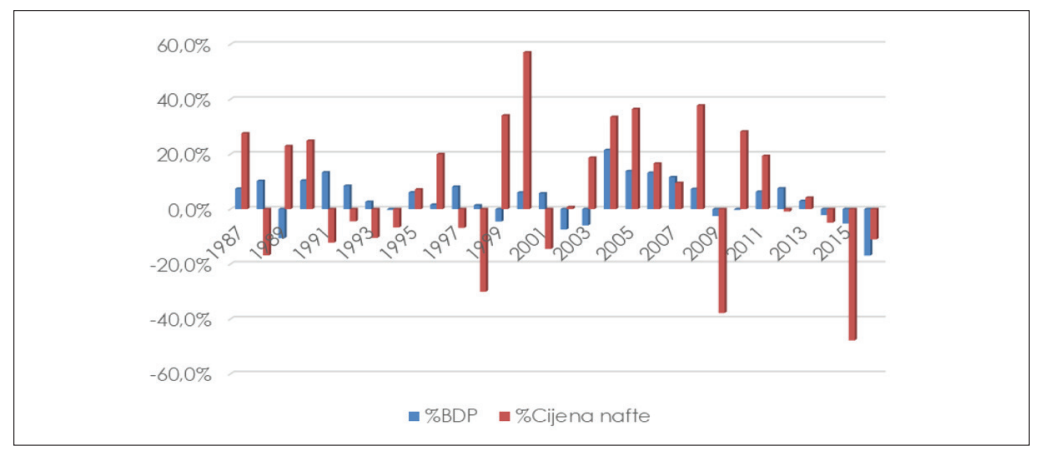

Izvor: MMF, Svjetska banka. 
Jošić, H., Maček Pandak, F.

Nizozemska bolest u

Bolivarijanskoj Republici Venezueli

Slika 3.Zemlje prema zalihama sirove nafte, mlrd. barela (2016.)

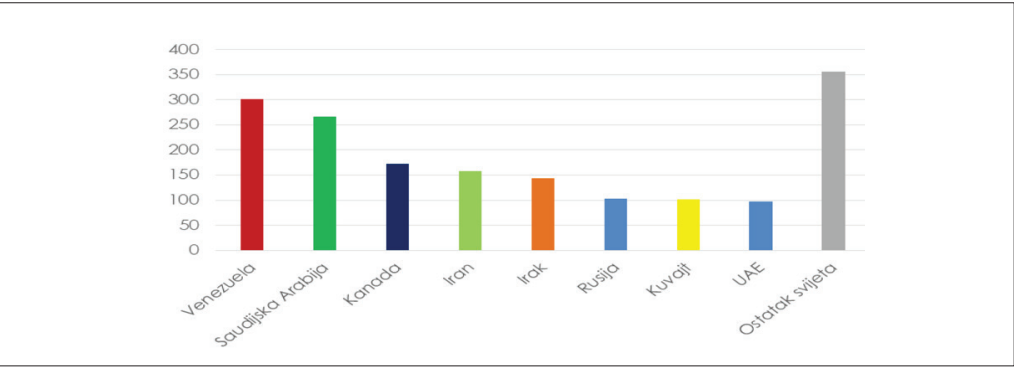

Izvor: British Petroleum.

kroz posljednjih 15 godina još povećala te je danas izvoz nafte glavni izvor deviznih rezervi iz kojih se financiraju vanjski dugovi te mnoštvo uvoznih dobara koje Venezuela više ne može proizvesti. Nadalje, udio industrije nafte u BDP-u iznosi oko 25\% (OPEC, 2017.). lako zbog utjecaja ostalih privrednih sektora te globalnih gospodarskih kretanja, ne postoji linearna veza između promjene cijene nafte i stope promjene BDP-a, iz Slike 2. je vidljivo da rast cijene nafte djeluje pozitivno na BDP kao i obrnuto. Britanski naftni div BP (bivši British Petroleum) u svojem godišnjem izvješću iz 2017. godine tvrdi da Venezuela ima najveće dokazane konvencionalne zalihe sirove nafte na svijetu, 301 milijardu barela. Većina venezuelanske nafte nalazi se u 4 glavna nalazišta: Maracaibo, Falcon, Apure i Oriental, a uz konvencionalne zalihe Venezuela ima i najveće svjetske zalihe teške sirove nafte (530 milijardi barela) uz područje rijeke Orinoco, no njena iskoristivost je manja u odnosu na konvencionalnu. Uz naftu, Venezuela ima i značajne depozite ugljena i zemnog plina koji se uglavnom koriste kao input u proizvodnji nafte. Na Slici 3. nalazi se usporedba naftnih zaliha Venezuele s ostalim državama sa značajnim zalihama.

Tijekom štrajka u PDVSA vlada je donijela novi zakon o ugljikovodicima kojim je smanjila poslovnu autonomiju privatnih naftnih tvrtki. Prema zakonu, istraživanje i eksploatacija fosilnih goriva dopuštena je samo poduzećima u natpolovičnom državnom vlasništvu. lako se zakon u početku nije provodio retroaktivno, idućih godina donesene su nadopune koje se odnose na već dobivene koncesije čime započinje nacionalizacija venezuelanske naftne industrije. Pregled događaja vezanih uz naftnu legislativu od dolaska Chaveza na vlast iznio je 2011. međunarodni pravnik iz King \& Spaldinga, Alberto F. Ravell: 2004. i 2006. godine amandmanima je porez na vađenje teške nafte povećan na konačnih $33,33 \%$ te je uveden dodatan porez na naftne prihode. Godine 2006. država jednostrano raskida 32 naftna ugovora s poduzećima s kojima su ugovori sklopljeni 1990-tih. Poduzeća dobivaju ultimatum: ili će preći na mješoviti državno-privatni sustav poslovanja ili moraju napustiti zemlju. Godine 2007. isti ultimatum dan je i podružnicama Exxona, Conoco Phillipsa, Chevrona, OPIC Karimuna i CNPC-a uz prijetnju nacionalizacije imovine u slučaju odbijanja. Istekom roka od 4 mjeseca navedene tvrtke odbijaju nove ugovore te pokreću međunarodnu arbitražu protiv Venezuele. Uslijed oporavka nafthe industrije nakon recesijske 2008. godine, vlada 2009. godine donosi novi zakon o ugljikovodicima kojim omogućuje nacionalizaciju svih aktivnosti vezanih uz eksploataciju prirodnih bogatstava Venezuele bez obveze davanja kompenzacija stranim i privatnim poduzećima koja su obavljala te djelatnosti. Vojska je zauzela preostalu privatnu imovinu desetaka poduzeća u mješovitom vlasništvu te je ona pripojena nacionalnoj kompaniji, PDVSA. Bivši suvlasnici također pokreću međunarodnu arbitražu. Godine 2011. uveden je novi porez prema kojem porezna obveza proizvođača i izvoznika nafte ovisi o rastu cijene nafte.

$\mathrm{Na}$ rukovodeća mjesta nacionaliziranih postrojenja uglavnom su došli kadrovi bliski vlasti koji su neefikasno vodili poduzeća. Manjak ulaganja u modernizaciju i održavanje kao i ogromne sub- 
vencije za gorivo na domaćem tržištu doveli su do konstantnog opadanja proizvodnje i naftnih prihoda. Hanke (2017.) s Cato instituta navodi da PDV$S A$, koja je postala istoznačna $s$ venezuelanskom naftnom industrijom, ima najnižu stopu iskorištavanja svojih naftnih zaliha na svijetu, svega 0,35\% (godišnja proizvodnja/dokazane prošlogodišnje zalihe). Prema tome, medijan vremena potrebnog PDVSA za vađenje i prodaju jednog barela nafte iznosi 198 godina što znači da će prema sadašnjoj stopi iskorištavanja dokazanih izvora, PDVSA u idućih 198 godina iscrpiti i prodati tek pola svojih današnjih naftnih rezervi. Za usporedbu, Exxonovo medijansko vrijeme iznosi 8,2 godine, a stopa iskorištavanja $8,15 \%$. U tim uvjetima i s prosječnim tržišnim diskontnim stopama ekonomska vrijednost, odnosno čista sadašnja vrijednost trenutno dokazanih venezuelanskih naftnih rezervi je zanemariva.

Korištenje naftnih prihoda za financiranje fiskalne ekspanzije i loše upravljanje doveli su do gomilanja dugova te početkom 2017. središnja banka koristi vanjskotrgovinske rezerve kako bi spasila PDVSA od stečaja. Prema izvještaju Reutersa iz 2014., cijena litre benzina na benzinskoj postaji iznosi oko 1,5 američka centa, 28 puta manje od troška proizvodnje, odnosno čak 50 puta manje u slučaju dizela. Isti izvor procjenjuje da venezuelanska naftna industrija na subvencioniranim cijenama goriva gubi oko 12,5 milijardi dolara godišnje Reuters (2017.). Naftni prihodi su dodatno smanjeni zbog prodaje prijateljskim zemljama po povlaštenim uvjetima ili uz odgodu plaćanja.Jedini značajniji vanjskotrgovinski partner koji plaća punu cijenu nafte bez odgode su $S A D$, pa Venezuela trenutno ovisi o trgovini s njima.

\section{Međunarodna razmjena Venezuele}

Venezuela je od stjecanja samostalnosti bila orijentirana na izvoz. Kako je navedeno, tijekom 19. i 20. stoljeća glavni izvozni proizvod bili su kava, kakaovac i duhan koje je zamijenila nafta i naftne prerađevine nakon njezina otkrića. Prema podacima Obzervatorija za ekonomsku složenost, Venezuela najveći obujam vanjske trgovine ostvaruje sa SAD-om koji je 2015. činio 29\% ukupnog uvoza i 43\% ukupnog izvoza Venezuele. Unatoč tome, predsjednik Hugo Chavez često se suprotstavljao američkoj politici prema Južnoj Americi te je 2004. ugovorom s Kubom stvorio Bolivarijanski savez za narode Amerike (španj. Alianza Bolivariana para los Pueblos de Nuestra América - ALBA), kao protutežu Ugovoru o međuameričkoj slobodnoj trgovini (FTAA) koji su podržavale SAD. ALBA se temelji na međusobnoj financijskoj pomoći i robnoj trampi te na taj način izbjegava korištenje dolara kao valute za izravnanja, no međunarodna razmjena Venezuele s ostalim članicama ALBA-e je gotovo zanemariva te je izgledno da one koriste svoje članstvo kako bi došle do jeftine nafte (Plummer, 2015.). Drugi najveći trgovinski partner je Kina s kojom je 2015. ostvareno između 18\% i 19\% ukupne razmjene te s kojom je 2007. godine osnovan zajednički kinesko-venezuelanski fond preko kojega kineska razvojna banka ulaže u Venezuelu, a otplate se vrše u
Jošić, H., Maček Pandak, F.

Nizozemska bolest u Bolivarijanskoj Republici Venezueli

Slika 4. Struktura izvoza Venezuele (2015.)

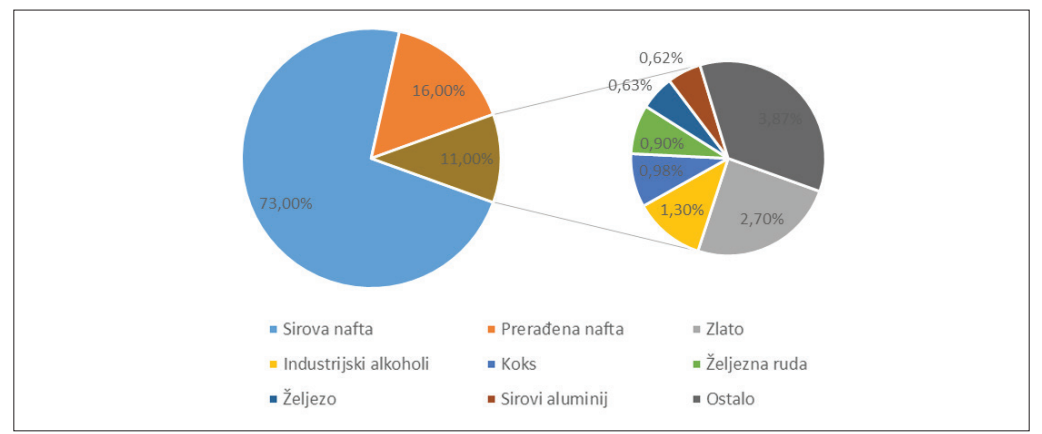

Izvor: Observatory of Economic Complexity. 
Jošić, H., Maček Pandak, F.

Nizozemska bolest $u$

Bolivarijanskoj Republici Venezueli
Slika 5. Struktura uvoza Venezuele (2015.)

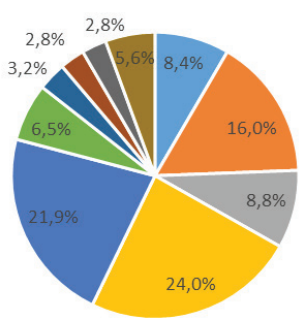

$$
\begin{array}{lll}
\text { m Prerađena nafta } & \text { = Lijekovi i kemijski proizvodi }=\text { Prijevozna sredstva } \\
\text { = Strojevi } & \text { - Hrana } & \text { = Metali } \\
\text { - Plastika i guma } & \text { - Papir } & \text { - Tekstil i obuća }
\end{array}
$$

Izvor: Observatory of Economic Complexity.

nafti. Ostali značajni trgovinski partneri su Indija koja čini oko 17\% izvoza te čija nacionalna naftna kompanija ima koncesiju u Venezueli, i Brazil, najveći regionalni partner iz kojeg potječe oko 11\% uvoza. Također, Venezuela je bila jedan od 5 osnivača Organizacije zemalja izvoznica nafte (OPEC), a Chavez je bio poznat po lobiranju za ograničenje proizvodnje kako bi se povećala cijena nafte.

Trgovinska ograničenja, vladine intervencije i pravna nesigurnost otjerali su iz zemlje većinu stranih poduzeća koja su pokretala tehnološki složeniju proizvodnju, a nizozemska bolest je uništila poljop- rivredu pa danas gotovo sav izvoz čine nafta i nusproizvodi te sirovine. Struktura izvoza prikazana je na Slici 4., a prema podacima Svjetske banke izvoz je 2015.godine iznosio 37,2 mlrd.USD.Uz to, devizna ograničenja i komplicirana birokracija dodatno otežavaju trgovinu pa je Svjetska banka na Doing Business ljestvici Venezuelu rangirala kao 187. od 190 zemalja, s troškovima uvoza i izvoza 3 do 4 puta višima od južnoameričkog prosjeka (World Bank, 2017.). U prosincu 2016. Južnoameričko slobodno tržište (MERCOSUR) suspendiralo je članstvo Venezuele zbog autokratskog načina vladanja predsjednika Madura te sumnje u namještanje

Slika 6. Međunarodna razmjena Venezuele u odnosu na cijenu nafte (1995. - 2016.)



Izvor: Svjetska trgovinska organizacija, Svjetska banka. 
izbora. U ljeto 2017. suspenzija je produžena na neodređeno vrijeme.

Zbog propasti domaće proizvodnje Venezuela danas uvozi gotovo sve, uključujući i dio naftnih prerađevina za domaću potrošnju (Gillespie, 2016.) jer domaća naftna industrija ne može istovremeno zadovoljiti domaću potražnju te ispunjavati obveze iz trgovinskih ugovora o kojima ovisi priljev deviza i međunarodna likvidnost zemlje. Struktura uvoza vidljiva je iz Slike 5. Uvoz je prema podacima Svjetske banke 2015. iznosio 36,5 mlrd USD.

Venezuela svoje devizne rezerve formira uglavnom prihodima od prodaje nafte, a budući da je nafta glavni izvozni proizvod te da devizna ograničenja onemogućavaju slobodan protok stranog novca kroz zemlju, obujam uvoza izravno ovisi o izvozu koji ovisi o cijeni nafte i kapacitetu naftne industrije. Za vrijeme rastućih cijena nafte stvorene su devizne rezerve, koje su 2008. godine dosegle 43,3 milijarde USD, te su bile dostatne za pokriće tekućih dugova i uvoz potrebnih proizvoda, no kao ni u ostatku gospodarstva, pri formiranju rezervi nije uzeta u obzir mogućnost pada cijene nafte. Suočena s padom cijene nafte, Venezuela je od 2014. do 2017. potrošila $3 / 4$ tih rezervi (Worley, 2017.) te je sada, kako bi izbjegla bankrot, prisiljena preostale rezerve koristiti za servisiranje dugova. Zbog nedostatnosti domaće proizvodnje i nemogućnosti uvoza, ali i politike koja zagovara nacionalnu samodostatnost, Venezuela i dalje održava vanjskotrgovinski suficit unatoč nestašicama osnovne robe.
Veza između obujma vanjskotrgovinske razmjene i naftnih prihoda prikazana je na Slici 6.

\section{Ekonomska politika u Venezueli}

Venezuela je većinu svoje moderne povijesti, osim dijela 1980-ih i 1990-ih, vodila ekspanzivnu fiskalnu politiku kojom se izravno povećavao životni standard građana putem subvencija na potrošačka dobra, otvaranja radnih mjesta u javnom sektoru i državnim poduzećima te programa socijalne pomoći. Na taj su način vlasti iz naftnih prihoda umjetno održavale ostale gospodarske sektore na životu te sprječavale socijalno raslojavanje, ciljajući na posljedice, a ne uzroke problema. Državna potrošnja ovisila je o cijeni nafte te je u vremenima skupe nafte davala dodatan zamah rastu gospodarstva, ali je pri padu cijena nafte ugrožavala javne financije, a njeno smanjenje je izravno ugrožavalo standard znatnog dijela stanovništva. Fiskalna politika trenutnog predsjednika Nicolasa Madura i njegovog prethodnika Huga Chaveza ne razlikuje se znatno od politika vlada iz vremena skoka naftnih cijena 1970-ih te su i rezultati slični. Za vrijeme gospodarskog uzleta od 2003. do 2008. godine stopa nezaposlenosti u Venezueli se više nego prepolovila, dijelom zbog zapošljavanja u javnom sektoru, ali dijelom i zbog utjecaja povećane potražnje na privatni sektor. Programi socijalnih misija koji su se bavili besplatnim obrazovanjem i dokvalifikacijom odraslih znatno su povećali zapošljivost siromašnijeg i ugroženijeg dijela stanovništva.

Slika 7. Vladina potrošnja, mlrd. dolara (1998. - 2013.)



Izvor: MMF. 
Jošić, H., Maček Pandak, F.

Nizozemska bolest $u$

Bolivarijanskoj Republici Venezueli
Najviše zaposlenih bilo je u sektoru komunalnih i socijalnih usluga kojeg uglavnom financira država (Weisbrot i Sandoval, 2009.). Trgovina i ugostiteljstvo čine najveći udio privatnog sektora, a slijedi in industrija, prijevoz te telekomunikacije i građevinarstvo, koje je također zbog socijalne gradnje, ali i rasta potražnje u periodu od 2003. do 2008. godine povećalo potrebu za radnicima. Ekspanzivna fiskalna politika dovela je do smanjenja „neformalnog rada", u kojem je u periodu od 2002. do kraja 2015., prema podacima Nacionalnog instituta za statistiku, sudjelovalo između 36,5\% i $54,4 \%$ radne snage. Prema podacima istog instituta stopa nezaposlenosti je krajem 2015. iznosila 6,7\%, što je znatno smanjenje u odnosu na $16,2 \%$ s kraja 2002. godine.

Gospodarska i fiskalna ekspanzija Venezuele prikazana je na Slici 7. te počinje nakon gušenja štrajka kada ujedno i počinje rast cijene nafte. Od tada pa do sloma javnih financija nakon ponovnog pada cijene nafte 2014. godine, vladina potrošnja je rasla i u apsolutnom iznosu i u relativnom odnosu na BDP uz manji prekid tijekom globalne recesije 2008. godine.

Najveći dio proračunskih sredstava trošio se na transferna plaćanja koja se odnose na pomoć za siromašne, samohrane roditelje, udovice i nezaposlene, a prima ih oko 7\% stanovništva. Broj primatelja transfera i broj umirovljenika koji primaju mirovinu iz državnih fondova (Carlson, 2012.) s vremenom je povećan. Nakon transfera, druga najveća proračunska stavka su kapitalni rashodi koji obuhvaćaju izgradnju prometne, obrazovne, zdravstvene i stambene infrastrukture u sklopu bolivarijanskih misija te plaće za javne i državne službenike čiji se udio povećao s 14,5\% 1998. godine na oko 17\% 2008. godine.

Tradicionalno najvažnija stavka na prihodovnoj strani proračuna su naftni prihodi koje čini dio dobiti koji PDVSA transferira u proračun. Drugi najvažniji izvor javnih prihoda su porezi koji dobivaju na važnosti uslijed rasta privatnog sektora, ali i zbog smanjenja naftnih prihoda uslijed pada cijene nafte i problema u naftnoj industriji. Međutim, porezna je politika uvijek bila u drugom planu te se javne financije prvenstveno oslanjaju na naftu.

Prema podacima venezuelanskog Nacionalnog ureda za javne financije, najveći dio javnog duga
Venezuele, oko 68\%, odnosno 100 milijardi USD, čini domaći dug koji je isključivo denominiran u bolivarima. Državna poduzeća i vlada preferirali su zaduživanje u zemlji zbog tečajnih razlika, ali i mogućnosti monetizacije duga. Kontrolirani devizni tečaj i kamatna ograničenja stvorila su potražnju na domaćem tržištu dužničkih papira, no inflacija od 20 do $30 \%$ godišnje pretvorila je visoke nominalne stope povrata u negativne realne te tako izbrisala dio duga. Nacionalni ured za javne financije također daje podatke 0 instrumentima duga i kreditorima. Preko pola domaćeg duga sastoji se od obveznica koje se prodaju na domaćem tržištu i manjim dijelom od trezorskih zapisa, a oko 40\% čini neizravan dug. Gotovo $70 \%$ instrumenata domaćeg javnog duga ima fiksnu kamatnu stopu. Vanjski dug je gotovo isključivo denominiran u američkim dolarima te je u prvom tromjesečju 2017. godine iznosio oko 46,6 milijardi USD. Najveći udio vanjskog duga, oko $77 \%$, sastoji se od desetogodišnjih državnih obveznica. Najveći međunarodni kreditori Venezuele su Međuamerička razvojna banka (BID) i Razvojna banka Latinske Amerike (CAF) koje zajedno drže oko $11 \%$ duga te vlade Rusije i Brazila s udjelom od $9 \%$. Kina preko svoje razvojne banke (CDB) kroz zajmove financira zajednički kinesko-venezuelanski fond (FCCV) koji ulaže u projekte u Venezueli. Ti se zajmovi, umjesto novčane otplate, kompenziraju odgođenim isporukama nafte. Ostatak vanjskog duga sastoji se uglavnom od zajmova poslovnih banaka.

Nije izgledno da će domaći dug dovesti do bankrota države jer je, na štetu vjerovnika, većinom obezvrijeđen inflacijom, no vanjski dug predstavlja ozbiljan problem s obzirom da su devizne rezerve pale na rekordno niskih 10 milijardi USD, a rast cijena nafte kojim bi se povećao priljev deviza nije izgledan. Zbog smanjenja proizvodnog kapaciteta i pada cijena nafte, Venezuela ne može izvesti dovoljno nafte da istovremeno uprihodi dovoljno deviza za otplatu dolarskih dugova i poštuje obveze iz ugovora prema kojima dugove kompenzira naftom. Situaciju pogoršava i odljev kapitala iz zemlje te rekordni deficit državnog proračuna o kojem egzistencijalno ovisi veliki broj građana. Struktura javnog duga prikazana je na Slici 8.

U ovaj pregled su uključeni samo dugovi vlade, ministarstava i državnih institucija, ali ne i dugovi 
Slika 8. Komponente javnog duga Venezuele (milijuni USD) (1997. - 2017.)

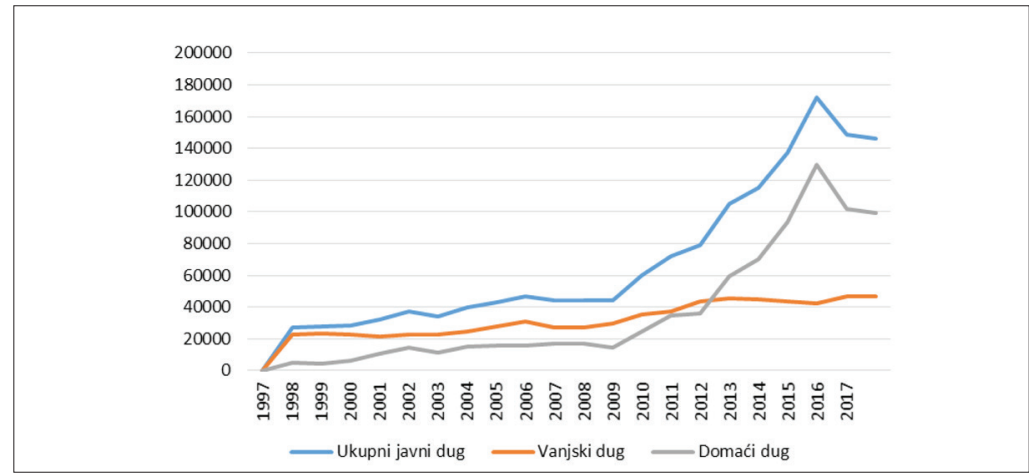

Izvor: Oficina Nacional de Crédito Público Finanzas.

PDVSA i drugih državnih konglomerata koji su također velikim dijelom u dolarima i pod državnim jamstvima, a s kojima vanjski dug prelazi 140 milijardi USD. Također, nisu uključene ni obveze koje proizlaze iz FCCV-a.

Godine 2003. vlada u sklopu socijalnih programa uvodi cjenovna ograničenja na osnovne prehrambene proizvode i neku robu široke potrošnje. Sada se domaća industrija i poljoprivreda, koja se nikad nije oporavila od nizozemske bolesti, $s$ jedne strane suočavaju s fiksiranim cijenama outputa, a s druge, rastućim cijenama inputa. Znatan pad ponude u odnosu na potražnju doveo je do nestašica koje su se povećavale s rastom inflacije. Argentinski novinar Daniel Lozano prenosi da se udio nedostupnih proizvoda u prosječnoj potrošačkoj košarici povećao s 5\% 2003. na 70\% krajem 2015. (Lozano, 2016). Državne intervencije te političko-pravna nestabilnost uzrokovali su bijeg kapitala iz zemlje, pa je vlada 2003. osnovala CADIVI, agenciju za kontrolu valuta koja je fiksirala tečaj bolivara prema dolaru na 1600:1. Uvedena su i količinska ograničenja građanima na držanje stranog novca, a poduzeća su sva sredstva u stranim valutama morala držati na računima kod središnje banke te su u transakcijama morala koristiti samo službene, administrativno određene tečajeve. To je dovelo do simultanog nastanka crnog valutnog tržišta na kojemu je bolivar vrijedio daleko manje nego prema službenom tečaju. Nastao je začarani krug u kojem su uvozne cijene zbog valutnih ograničenja rasle na razine koje odgovaraju crnotržišnom tečaju, koji raste brže od službenog vladinog tečaja.

Kao što je istaknuto, nakon Chavezove smrti 2013. godine, novi predsjednik postaje Nicolas Maduro, koji pokušava ugasiti crno tržište uvođenjem niza novih tečajnih sustava koji i dalje drže bolivar nerealno jakim. Prvi u nizu bio je SICAD, odnosno Sistema Complementario de Administración de Divisas koji je nudio realniji odnos bolivara prema dolaru u odnosu na CADIVI-jev tečaj. Međutim, SICAD je bio fiksni tečaj pa je zbog inflacije vrlo brzo postao precijenjen. 2014. godine uveden je SICAD 2 koji je bio identičan SICAD-u osim što je bolivar prema njemu vrijedio manje u odnosu na dolar. Kako je bolivar nastavio deprecirati ni taj tečaj nije prihvaćen $u$ javnosti. Paralelno $s$ uvođenjem SICAD-a 2, CADIVI se ujedinila s Centrom za vanjsku trgovinu te su simultano vrijedila dva službena tečaja od kojih niti jedan nije bio realan. Godine 2015. uveden je Sistema Marginal de Divisas (SIMADI), novi sustav koji se trebao bazirati na odnosima ponude i potražnje za dolarom i bolivarom, no i on je samo fiksirao vrijednost bolivara za dolar te, kao ni njegovi prethodnici, nije uzimao u obzir sve brže rastuću inflaciju. Tečajni sistemi prikazani su na Slici 9.

Uoči visoke inflacije 2016. godine, službeni tečajevi su sve brže počeli gubiti veze sa stvarnim stanjem i crnim tržištem pa su svi dotadašnji tečajni sustavi ukinuti i zamijenjeni novim. Novi sustav sastojao se od fiksnog (DIPRO) tečaja prema kojem se odvijaju
Jošić, H., Maček Pandak, F.

Nizozemska bolest $\mathrm{u}$ Bolivarijanskoj Republici Venezueli 
Jošić, H., Maček Pandak, F.

Nizozemska bolest $u$ Bolivarijanskoj Republici Venezueli

Slika 9. Tečajevi i tečajni sustavi Venezuele, USD/FEV (ožujak 2013. - ožujak 2017.)

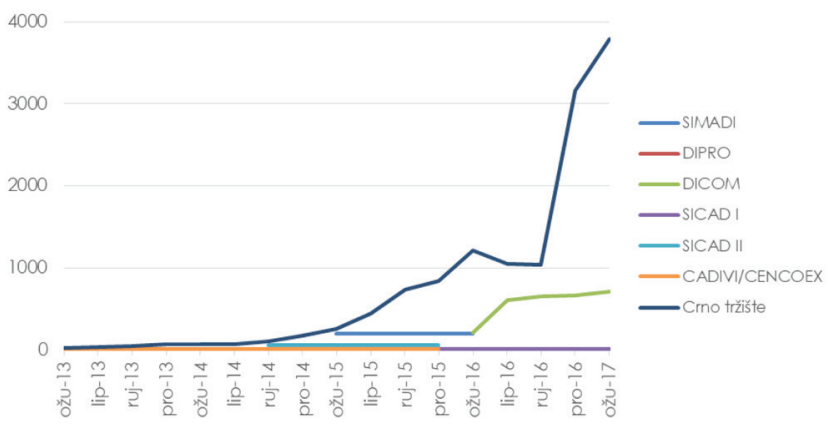

Izvor: Banco Central de Venezuela, DolarToday.

transakcije za nužne proizvode poput hrane i lijekova te plutajućeg (DICOM) tečaja, koji vrijedi za ostale transakcije. DIPRO je fiksiran na razini od 10 bolivara za 1 dolar, dok DICOM i dalje zaostaje za realnim tečajem. Unatoč promjenama tečajnih sistema, ukidanje količinskih ograničenja na tržištu deviza nikad nije bilo u planu. Trenutno, prema zakonu, venezuelanski građani imaju pravo kupiti 500 dolara svaka 3 mjeseca, dok poduzeća smiju kupiti do 400.000 dolara mjesečno (Banco Central de Venezuela, 2017.). Osobe bliske vlasti koje imaju nesmetan pristup višetečajnom deviznom sustavu koriste razliku u tečajevima kupujući dolar po jeftinijem tečaju, zatim kupujući robu koju pre- prodaju višestruko skuplje na crnom tržištu te tim novcem ponovno kupuju dolare. Devizna arbitraža te krijumčarenje roba koje su nedostupne postali su unosan posao za ljude u pograničnim područjima i one s političkom zaštitom.

\section{Problem inflacije i bijega kapitala}

Gospodarski rast u kombinaciji s ekspanzivnom monetarnom politikom, kojom je djelomično financirana javna potrošnja, ubrzo su doveli do inflacije. Dok je cijena nafte rasla, vlada je inflaciju smatrala manjom smetnjom pa su protuinflacijske mjere obuhvaćale konstantna povećanja minimalne plaće te obuzdavanje privatne potrošnje. $U$ tu je svrhu

Slika 10. Indeks potrošačkih cijena u Venezueli, 1997. - 2016.(2007.=100)

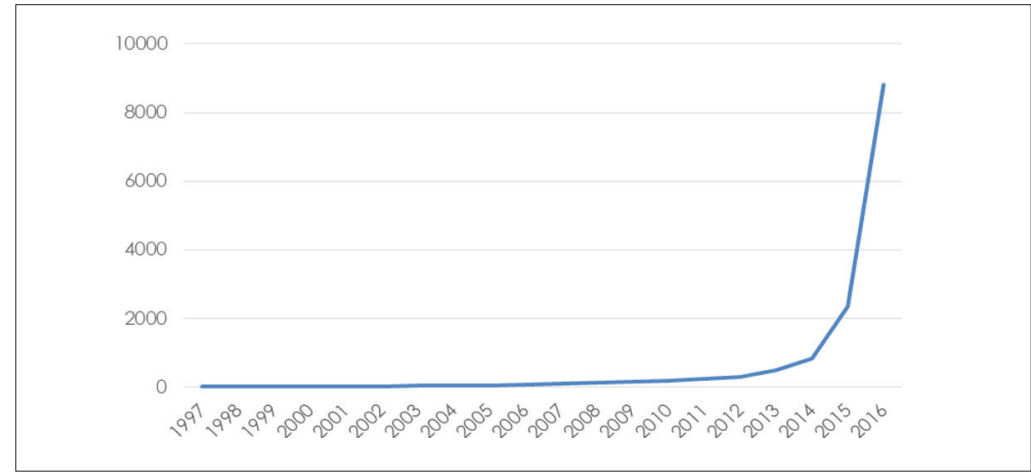

Izvor: MMF. 
uveden porez na luksuzna i određena uvozna dobra, kao i porez od 1,5\% na vrijednost bankovnih transakcija između poduzeća, čime se pokušalo smanjiti prekomjernu likvidnost sustava (Carlson, 2007.). Godine 2008., s prestankom rasta cijene nafte, uvedena je nova novčana jedinica bolivar fuerte ( $F E V$, jaki bolivar") koja je vrijedila 1000 starih bolivara, no time nisu riješeni uzroci problema. Uslijedio je rast potrošačkih cijena prikazan na Slici 10., a domaća poduzeća obvezana cjenovnim ograničenjima morala su prodavati po puno manjim administrativno određenim cijenama koje često nisu pokrivale ni nabavne cijene inputa što je uzrokovalo nestašice.

Godine 2013. počinje smanjenje cijena nafte te vlada manjak naftnih prihoda nadomješta monetizacijom duga. Inflacija te godine raste na $40 \%$, dvostruko više od uobičajene godišnje razine, a 2014. se povećava na $60 \%$, dok velik pad cijena nafte uzrokuje rast cijena od 180\%. 2015., te 2016. godine venezuelanska središnja banka prestaje objavljivati podatke o inflaciji, no procjene iznose oko $800 \%$ za tu godinu te preko $1000 \%$ za 2017 .godinu. Porast likvidnih sredstava (agregat M2) u optjecaju prikazan je na Slici 11.

Minimalna plaća, koju prima većina zaposlenih, često je povećavana kako bi prihodi pratili rast cijena te od srpnja 2017.godine iznosi 97,5 tisuća bolivara, što je prema neslužbenom tečaju oko 12,5 dolara (Gillespie, 2017.), a prema službenom plutajućem tečaju oko 3 puta više. Plaća se osim u novcu izdaje i u bonovima za hranu i robu široke potrošnje, koji se mogu koristiti u državnim trgovinama, ukoliko ima robe.

lako je vlada strogim deviznim propisima pokušala spriječiti odljev kapitala, deprecijacija bolivara i nemogućnost pribavljanja stabilne valute te raspad gospodarstva otjerali su strana poduzeća iz zemlje. Propast domaćih kooperanata te nemogućnost nabave sirovina natjerali su korporacije poput Coca Cole, Johnson \& Johnsona i McDonaldsa da napuste svoje venezuelanske projekte, što je dodatno pojačalo nestašicu. lako su se nestašice roba u vladinim trgovinama povremeno javljale i prije, smanjena mogućnost uvoza zbog pada deviznih rezervi, u kombinaciji sa sve više administrativno određenih cijena, uključujući u jednom razdoblju i cijene potrošačke elektronike (Aranguren, 2014.), činili su nestašice sve češćima. Veliki broj domaćih prodavača obustavio je poslovanje, a preostali su, unatoč strogim kaznama, sve veći dio svog asortimana počeli prodavati na crnom tržištu. Stvorio se začaran krug u kojem se sve manje robe prodaje po sve većim cijenama, a država sve više gubi kontrolu nad tržištem. Belen Wu s instituta John Hopkins 2016. godine navodi da su se poduzeća koja su imala značajna sredstva u bolivarima, a nisu mogla dezinvestirati, okrenula ulaganjima u nekretnine koje bolje čuvaju vrijednost (Belen Wu, 2016.). Kriza se odrazila i na tržište kapitala. Nominalna vrijednost indeksa burze u Caracasu (IBVC) agresivno raste u korak s inflacijom, no njegova realna vrijednost u dolarima pala je na razine iz 1990 -ih, a isto

Slika 11. M2 u mlrd. bolivara (1997. - 2017.)

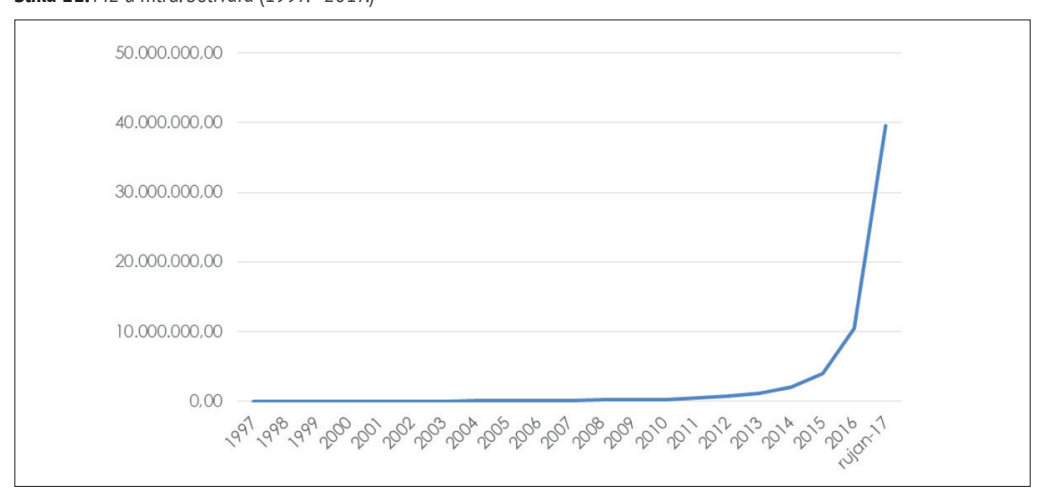

Izvor: Banco Central de Venezuela.

Jošić, H., Maček Pandak, F.

Nizozemska bolest $\mathrm{u}$ Bolivarijanskoj Republici Venezueli 
Jošić, H., Maček Pandak, F.

Nizozemska bolest $u$

Bolivarijanskoj Republici Venezueli vrijedi i za bankovne depozite koji su se od 2010. nominalno više nego udeseterostručili, ali su realno obezvrijeđeni. Smatra se da realna vrijednost dionica pada sporije od realne vrijednosti novca pa neki od preostalih ulagača ipak koriste venezuelansku burzu kao instrument hedginga u odnosu na bolivar.

\section{Zaključak}

Stoljetno baziranje gospodarstva na samo jednom faktoru, čije je kretanje izvan državne kontrole, a koji je pritom gušio ostale privredne grane pokazalo se lošim i po gospodarstvo i po stanje u društvu. Stvoren je sustav u kojem država iz svojih prihoda financira sektore koje je tržište procijenilo nekonkurentnima kako bi „kupila“ socijalni mir te se generacijama razvijao sustav korumpiranih i političkih podobnih. Prestankom rasta cijene nafte venezuelansko gospodarstvo 2012. počinje stagnirati, a s početkom negativnog trenda na naftnom tržištu ulazi u recesiju, i konačno u krizu. S obzirom da se proizvodni kapacitet venezuelanske naftne industrije smanjuje iz godine u godinu ni oporavak cijene nafte ne bi riješio probleme, već bi za održivost sadašnje venezuelanske privrede bio potreban stalan rast cijene nafte po sve većoj stopi. Zbog neizvjesnosti podmirivanja obveza, Venezuela po sve lošijim uvjetima dolazi do stranog novca na tržištu dugova. Domaća privatna proizvodnja propada zbog cjenovnih ograničenja dok državna poduzeća godinama smanjuju output zbog ograničene mogućnosti nabave sirovina, manjka kvalificiranog kadra i korupcije. Korupcija, koja korijene vuče još od osamostaljenja, nesmetano se razvijala u sustavu u kojem su politika i gospodarstvo međusobno isprepleteni. S obzirom da su domaći izvori kapitala iscrpljeni, a potreban rast cijene nafte nije izgledan, Venezuela bi rješenje svojih problema trebala tražiti u inozemnim investicijama i liberalizaciji tržišta. Trenutna vlast se tome oštro protivi dok oporba dobiva sve veću potporu naroda, pa se Venezuela uz ekonomsku trenutno nalazi i u političkoj krizi.

\section{Literatura}

Aranguren, E. L. (2014) La resaca del “dakazo”, un año después [online]. Puerto la Cruz: El Tiempo.com.ve. Dostupno na: http://eltiempo.com.ve/venezuela/situacion/la-resaca-del-dakazo-un-ano-despues/161509 [17.8.2017.].

Banco Central de Venezuela (2017) Este martes comenzó a operar nuevo DICOM [online]. Caracas: BCV. Dostupno na: http://www.bcv.org.ve/c4/notasprensa.asp?Codigo=13561\&0peracion=2\&Sec=False [20.8.2017.].

Belen Wu, M. (2016) Studies in Applied Economics: Issues in venezuelan monetary and economic reform [online]. Baltimore: Johns Hopkins University. Dostupno na: http://sites.krieger.jhu.edu/iae/files/2017/04/ Issues-in-Venezuelan-Monetary-and-Economic-Reform.pdf [17.8.2017.].

British Petroleum (2017) BP Statistical Review of World Energy June 2017. London: BP.

Buitrago, D. (2014) Venezuelan minister repeats pledge to raise domestic fuel prices [online]. London: Reuters. Dostupno na: https://www.reuters.com/article/venezuela-gasoline-idUSL2NOQB2S520140805 [2.8.2017.].

Carlson, C. (2007) Venezuela Implements New Taxes on Businesses, Cigarettes, Alcohol [online]. venezuelanalysis.com. Dostupno na: https://venezuelanalysis.com/news/2711 [2.8.2017.].

Carlson, C. (2012) Venezuela Adds More than 800,000 Welfare Beneficiaries in 2012 [online].venezuelanalysis.com. Dostupno na: https://venezuelanalysis.com/news/7569 [10.8.2017.]. 
Gillespie,P.(2016) Oil-rich Venezuela is now importing U.S. oil [online].Atlanta: CNN.Dostupno na: http:// money.cnn.com/2016/02/03/news/economy/venezuela-imports-american-oil/index.html [6.8.2017.].

Gillespie, P. (2017) Venezuela jacks up minimum wage for third time this year [online]. Atlanta: CNN. Dostupno na: http://money.cnn.com/2017/07/02/news/economy/venezuela-minimum-wage-hike/index. html [17.8.2017.].

Haggerty, R. A. (ur.) (1990) Venezuela: A Country Study [online]. Washington: GPO for the Library of Congress. Dostupno na: http://countrystudies.us/venezuela/21.htm [1.8.2017.].

Hanke, S. H. (2017) Venezuela's PDVSA: the World's Worst Oil Company. [online]. Cato Institute. Dostupno na: https://www.cato.org/publications/commentary/venezuelas-pdvsa-worlds-worst-oil-company [2.8.2017.].

International Monetary Fund (2017) World Economic Outlook. Washington D.C.: IMF.

Instituto Nacional de Estadística (2015) Nacional indicadores globales de la fuerza de trabajo, según sexo. Caracas: INE.

Lozano, D. (2016) Ni un paso atrás: Maduro insiste con su receta económica [online]. Buenos Aires: La Nacion. Dostupno na: http://www.lanacion.com.ar/1860362-ni-un-paso-atras-maduro-insiste-con-su-receta-economica [17.8.2017.].

OEC (2015) Venezuela [online]. Cambridge: The Observatory of Economic Complexity. Dostupno na: http://atlas.media.mit.edu/en/profile/country/ven/ [6.8.2017.].

OPEC (2017) Dostupno na: http://www.opec.org/opec_web/en/about_us/171.htm [17.8.2017].

Oficina Nacional de Crédito Público Finanzas (2017) Deuda Pública Nacional Del Gobierno Central. Caracas: $\mathrm{ONCP}$.

Plummer, R. (2015) Alba alliance ambitions lay bare Latin trade confusion [online]. London: BBC. Dostupno na: http://www.bbc.com/news/business-23515979 [6.8.2017.].

Ravell, A. F. (2011) A brief overview of venezuela's oil policies [online]. Lexology.com. Dostupno na: https://www.lexology.com/library/detail.aspx?g=01cf61f2-9591-4ac3-9ceb-59ac37090e13 [2.8.2017].

Reuters (2017) Venezuela's Dicom exchange rate eases 17 percent to 2,640 bolivars per dollar [online].London: Reuters. Dostupno na: https://www.reuters.com/article/us-venezuela-forex-idUSKBN19C24W [5.8.2017.].

Rosen, N. (2010) The Venezuelan Banking Crisis [online]. Columbia University: Initiative for Policy Dialogue. Dostupno na: http://policydialogue.org/publications/backgrounders/casestudies/the_venezuelan_ banking_crisis/en/ [1.8.2017.]. Bank.

The World Bank Doing Business (2017) Ease of Doing Business in Venezuela, RB. Washington: The World

Weisbrot, M., Ray, R., Sandoval, L. (2009) The Chávez Administration at 10 Years: The Economy and Social Indicators [online]. Washington D.C.: Center for Economic and Policy Research. Dostupno na: http:// cepr.net/documents/publications/venezuela-2009-02.pdf?phpMyAdmin=330ac50250f0at3851ad76r2963 [2.8.2017.].

Wilpert, G. (2004) Oil Company President Says Venezuela Will Audit its Oil Production [online]. venezuelanalysis.com. Dostupno na: https://venezuelanalysis.com/news/786 [29.8.2017.].

World Bank (2016) World Development Indicators. Washington: The World Bank.

Worley, W. (2017) Venezuela's foreign currency reserves down to just $\$ 10 \mathrm{bn}$, leaving country open to defaulting on debt [online]. London: Independent. Dostupno na: http://www.independent.co.uk/news/ business/news/venezuela-foreign-currency-reserves-10-billion-default-national-debt-south-america-a7607806.html [6.8.2017.].
Jošić, H., Maček Pandak, F.

Nizozemska bolest u Bolivarijanskoj Republici Venezueli 
